\title{
Reflections upon being university teachers and researchers at the time of the COVID-19 pandemic
}

Sigrid Stjernswärd1', Health-promoting Complex Interventions, Department of Health Sciences, Lund University Stinne Glasdam, Integrative Health Research, Department of Health Sciences, Lund University

'At first I was afraid, I was petrified', sings Gloria Gaynor in the song 'I will survive'. At first, we were excited, and we are ashamed to admit it. The world news was obviously unnerving; people were dying from an unknown virus, cities and countries locking down (Kinross, 2020). Nonetheless, news from far away can feel unreal and as if they do not concern you. At least, daily chores and conundrums tend to hijack one's attention at the expense of other people's suffering. It reminds of The Tale of the Fisherman and the Fish (Pushkin, 2011/1833) - the story about a fisherman who manages to catch a 'Golden Fish', which promises to fulfil any wish of his in exchange for its freedom. People die thousands of miles away, and we shut off the news as self-protection. Our goldfish dies and we start reflecting.

We work at Lund University in Sweden, which is situated in the Oresund region. This metropolitan region comprises eastern Denmark and Scania in southern Sweden. Denmark and Sweden, two neighbouring countries, adopted different COVID-19 strategies to handle the pandemic (Orange, 2020) and are the authors' respective countries of residence. Nonetheless, when Denmark closed its borders on 14 March, it felt unreal for both of us. We felt a tinge of excitement. How is this going to work? Is this really happening? Is it for real? Hanne-Vibeke Holst's (2018) book 'Like the Plague' came to our minds, and we silently wondered if things would really turn out the way she described them, if a pandemic was to hit the world. Our next thoughts: What will Sweden, and other countries, do? How will it affect us and our families? Third line of thought, which implications does it have for our workplace, employment and work conditions?

What we know for sure is that daily life changed from one day to the other. Our employers from the university sent frequent, urgent-marked emails entitled 'Corona news': 'We may need to "go digital" as of ... soon. Start planning for alternatives to classroom education and examinations. Work from home if you can. Follow the National Health Authority's recommendations.' and so on. One week later, we launched our first digital classroom. We have hardly been in the office, the one on campus, since mid-March. The same evening as Denmark closed its borders, we decided to change the focus of our research project in progress. 'Let's do something about the coronavirus', sounded the text message. 'I' $m$ in' was the spontaneous response. Three and a half weeks later, we launched a web-based survey about COVID-19 and social media, translated into eight different languages. With a 'little help from my (our) friends', to quote the Beatles, thanks to virtual international collaboration. From our respective home offices in Denmark and Sweden, we worked day and night, communicating through emails, video calls, text messages and common web-based programs and documents that both could reach online and work with simultaneously. In retrospect, our coping strategy was to 'research' us through a time of physical social distance with virtual social activities and a looming sense of loneliness and

${ }^{1}$ Contact: sigrid.stjernsward@med.lu.se 
isolation. Do we miss our office and work environment? No, and yes. Is working, i.e. research and education, different when carried out in the home office? Yes, and no. As a Dane, you could travel to Sweden, but as a Swede, you could not travel to Denmark. We succeeded in creating a meaningful community that brought human presence and friendship in the frontline, besides all regular work tasks. Many colleagues, just like us, also responded with an intensified focus on tasks related to teaching and administration at the workplace. Others, though few as far as we can tell, responded with frustration and despair to the acute changes that the job required. Historically, this is probably the only time that we, in a professional context, have largely not felt 'resistance to change'. Almost all, i.e. management, educators, students and the clinical teaching sites, accepted the terms and made a virtue out of necessity. COVID-19 spawned a national and international call for solidarity; solidarity to fight the disease and solidarity to maintain societal functions (Arora et al, 2020). Everyone at the university took on this calling. The overarching motto was and still is 'we just have to make it work'. Moreover, we did it.

Six months later: A summer break tinged by the pandemic followed an intense spring semester. The fall semester has just started. The pandemic is still classified as such, with subsequent management strategies varying from day to day, from country to country. We live and work in welfare states, which like many other countries are steered by a neoliberal ideology (Raimondi, 2020). The university is, consciously or not, part of it, however much we talk about teaching and applying critical thinking and thus viewing the world through analytical lenses. As during the spring semester, we still try to keep up the curricula of the different programmes and courses, we try to make it possible for the students to fulfil their education. We work hard. We have had to learn to use new digital tools, new pedagogical approaches, re-plan what we had previously planned as on-campus classroom education overnight. We need to be creative to make this work. We keep working, and not less than before the pandemic. Understatement. Mind you, we are happy to have a job, and one that is stimulating at that. To the best of our knowledge, we try to convert classroom-based education into web-based education. However, we are acutely aware that web-based teaching requires both technical competence and pedagogical skills, which are both difficult to acquire in a viable fashion within our regular work time, and on time-constrained terms (Conole, Dyke, Oliver \& Seale, 2004; Johnson, Veletsianos, \& Seaman, 2020). Workshops are set up, and colleagues help each other and work as an inspiration by sharing creative solutions. We use our lunch breaks and our free time to look up Facebook groups that focus on university teachers in the same situation as ours. We just have to make it work practically; this was the goal. Nonetheless, these challenges represent an added and challenging task in our already busy schedules. We want to produce competent graduated nurses, physiotherapists, occupational therapists, masters in medical sciences, doctoral students, and more. The world has to keep revolving, the world needs healthcare professionals, and the university needs its income, which is based partly on students enrolling and passing their exams, including tuition fees from non-European foreign students. During the spring, when the pandemic was new, health considerations were the highest priority and set the agenda for priorities at the university. Now the pandemic is regarded as a 'new everyday life' that we have to live with, and the neoliberal controls and thinking re-find their place in the system. Money overrules everything else. It costs money to lose students, which is why all first and second semester students in the fall must be taught by physical presence in the classrooms. By law, non-European international students need to be on campus to get an entry permit. Students in international programmes and courses, among others, are thus a prioritised group for on-campus teaching. Restrictions respected, naturally. Nonetheless, teachers are told to be ready to offer alternative solutions to compulsory classroom education and examination in case students cannot attend due to the coronavirus. Silently, we wonder if this is any different from any other condition or reason for not attending (non) compulsory classes? Is it enough to offer re-examination occasions? Whose interests are made a priority? Our starting point is that we are proponents of web-based education/teaching. 
Slowly but surely, the management is converting all employees' (more or less altruistic) virtual extra efforts from this exceptional period into ideas that are seized by the employers and transformed into 'normal states' in line with intentions for the future to become more digital with the development of distance-based courses. It strengthens the university's competitive position, enhancing its attractiveness in an increasingly 'digital' world and world economy. It is cheap both in terms of recorded lectures that can be re-played indefinitely, in principle; examinations can be replaced by multiple choice questions, which are top-down directed, and rooms do not have to be rented. We say yes to web-based courses and programmes, as it is a tremendous opportunity for many people to access and pursue an education. Nonetheless, we want to problematise how this development and 'new normal' are being handled henceforth. The work pace has been high, it works for a while. We must nevertheless think in terms of quality and sustainability, for our students, and thus society, and for ourselves, in terms of a sustainable work life. We want to highlight questions pertaining to pedagogy and work conditions. What about talking, evaluating and reflecting upon pedagogical skills, learning strategies, relations, social engagement, etc.? Humans, whether representing the management, educators or students, are social individuals, and it also costs (financially) to overlook this. We retain some students through this virtual venture, but we lose others. There is an inherent danger of managerial abuse and unreflective action when solidarityinduced extra efforts in an extraordinary world situation are (mis)used in attempts to convert these rapid, rash emergency efforts into economically advantageous everyday strategies for teaching at the university. Pedagogical knowledge and pedagogical strategies, online and face-to-face, must be driven by pedagogical arguments, not only economical arguments (Conole, Dyke, Oliver \& Seale, 2004; Johnson, Veletsianos, \& Seaman, 2020). Henceforth, both the students' and the teachers' competences and experiences must be taken into consideration together with scientific knowledge about methods, contents and evaluation regarding webbased education/teaching. This requires added resources in terms of time and competence development, for which the now less acute situation must make room.

The pandemic required fast acting. Fair enough. We did act fast. Evaluations of what worked and what did not work will inform us and help us move forward as best we can. Nevertheless, that fast pace cannot be upheld forever. We also need time to assess, reflect upon, and question what we do. And time to rest and recuperate. A collective burnout is also costly, in terms of human suffering and societal costs. The fast-paced system requires our full attention and demands its employees to act on the spot, here and now. We want to deliver high-quality education. We want to deliver high-quality teaching. We want to deliver high-quality web-based education /teaching solutions. However, maybe now is the time to make a pause for pedagogic reflection. If not, we may not survive...

Funding acknowledgement: No funding to declare.

No conflict of interest.

\section{References}

Arora, G., Kroumpouzos, G., Kassir, M., Jafferany, M., Lotti, T., Sadoughifar, R., Sitkowska, Z., Grabbe, S. \& Goldust, M.,2020. Solidarity and transparency against the COVID-19 pandemic. Dermatologic Therapy 33:e13359. DOI: $10.1111 /$ dth.13359

Conole, G., Dyke, M., Oliver, M., Seale, J., 2004. Mapping pedagogy and tools for effective learning design. Computers \& Education 43(1-2), 17-33. https://doi.org/10.1016/j.compedu.2003.12.018 
Holst, H-V., 2018. Ligesom pesten. Copenhagen, Gyldendal

Johnson, N., Veletsianos, G., Seaman, J., 2020. US Faculty and Administrators' Experiences and Approaches in the Early Weeks of the COVID-19 Pandemic. Online Learning 24(2), 6-21.

https://doi.org/10.24059/olj.v24i2.2285

Kinross P, Suetens C, Gomes DJ, Alexakis L, Wijermans A, Colzani E, Monnet DL., European Centre for Disease Prevention and Control (ECDC) Public Health Emergency Team, 2020. Rapidly increasing cumulative incidence of coronavirus disease (COVID-19) in the European Union/European Economic Area and the United Kingdom, 1 January to 15 March 2020. Euro Surveill. 25(11), pii=2000285. https://doi.org/10.2807/1560-

\section{ES.2020.25.11.2000285}

Orange, R. (2020). The Nordic divide on coronavirus: Which country has the right strategy? March 31. https://www.thelocal.com/20200331/the-nordic-divide-is-denmark-norway-sweden-right-or-wrong-oncoronavirus (Accessed September 7, 2020)

Pushkin, A., 2011(1833). The Tale of the Fisherman and the Fish. Translated by R. Chandler. Available at: http://www.stosvet.net/12/chandler/index9.html (Accessed September 7, 2020)

Raimondi, L. (2012). Neoliberalism and the Role of the University. PAACE Journal of Lifelong Learning 21, 39 50. https://doi.org/10.1080/1360144X.2017.1381966

\section{Betingelser for brug af denne artikel}

Denne artikel er omfattet af ophavsretsloven, og der må citeres fra den.

Følgende betingelser skal dog være opfyldt:

- Citatet skal være i overensstemmelse med "god skik"

- Der må kun citeres „i det omfang, som betinges af formålet"

- Ophavsmanden til teksten skal krediteres, og kilden skal angives ift. ovenstående bibliografiske oplysninger

(c) Copyright

DUT og artiklens forfatter
Udgivet af

Dansk Universitetspædagogisk Netværk 